\title{
Teaching Emperors: Transcending the Boundaries of Carolingian Monastic Communities*
}

\author{
Rutger Kramer
}

When the Frankish Emperor Charlemagne died in 814, his son Louis the Pious inherited the responsibility for an empire that proved a challenge to control. His new realm encompassed most of Western Europe, making it a sizeable territory to control from Aachen, the de facto seat of the empire. ${ }^{1}$ Moreover, his father and grandfather had set in motion an almost programmatic series of reforms that had been gaining momentum from the mid-8th century onwards. ${ }^{2}$ The overarching goal of this policy was nothing less than the salvation of all the people within the empire-to ensure that all subjects of the Carolingian rulers would be given the tools to be good Christians, so that they would not only lead good lives but also be rewarded in the afterlife. ${ }^{3}$

A primary tool for this was education, which could be anything from Christianizing pagans, combating heterodox movements, or simply making sure that members of the ecclesiastical hierarchy-from the highest archbishop to the lowliest village priest - were capable of performing the functions

* This article has benefited greatly from the insightful comments by Janneke Raaijmakers and Giorgia Vocino, as well as from the questions by the participants in the VISCOM conference from which this volume has sprung, the participants in the Princeton-Oxford-Vienna Graduate Exchange (May 2014), and the other authors in this section on Spiritual Communities. Research for this article was funded by the Austrian Science Fund (FWF): F42 Visions of Community.

1 On the challenges posed by the size of the empire, see Gravel, Distances, Rencontres, Communications; on the status of Aachen as the capital, see Nelson, "Aachen as a Place of Power", as well as McKitterick, Charlemagne, 157-71.

2 Generally, see Costambeys et al., Carolingian World. On Louis the Pious specifically, see among others Werner, "Hludovicus Augustus".

3 See among others De Jong, "Charlemagne's Church"; Brown, "Carolingian Renaissance"; McKitterick, Frankish Church; Smith, Europe after Rome, 217-30 and 239-52. It is tempting to compare the position of the Carolingian emperors to the medieval Islamic concept of mulk as described by Lohlker in this volume, but a more thorough comparison is needed to fully appreciate the extent to which these ideas overlap. For two different iterations of the concept, see Rabi', Political Theory of Ibn Khaldun, 137-50, or Anjum, Politics, Law and Community in Islamic Thought, 63-73 and 258-76.

(C) RUTGER KRAMER, 2016 | DOI 10.1163/9789004315693_015

This is an open access chapter distributed under the terms of the Creative Commons Attribution-

Noncommercial-NoDerivatives 3.o Unported (CC-BY-NC-ND 3.o) License. 
required of their position. The impetus behind the Carolingian cultural reform movement was provided by a need to ensure that everybody had been taught what they needed to know. ${ }^{4}$ The keyword for all this was correctio rather than reformatio, as the intention behind this policy was to improve and correct existing customs rather than to reform or rebuild the empire at an institutional level. ${ }^{5}$ Charlemagne and Louis the Pious would foster a climate among the elites of the realm in which mutual admonition was the norm, where intellectuals from all corners of the realm were gathered to elevate the learning of their colleagues to a higher level in a highly competitive yet ultimately productive environment. ${ }^{6}$ In the end, however, this court would go to lengths to present itself as a cohesive whole, acting more or less ex aequo with the emperor in spite of not being continuously in touch with one another. ${ }^{7}$ In doing so, the Carolingian intellectual elites combined the legacy of the Roman Empire with a Christian ideology that had been developed over the centuries, and so laid a solid foundation for their own political theology. ${ }^{8}$ Instead of reinventing the wheel, their goals were, firstly, to hammer out the details of their programme and, secondly, to make sure that all the subjects of the empire would be capable of learning the results of the high-level deliberations that took place at court. ${ }^{9}$ Ideally, once the members of the court had determined what needed to be done, they would impart this knowledge to their entourage - who would then pass it on again, so that in the end everyone was expected to live exemplary lives themselves based on the correctio as it trickled down from the court. ${ }^{10}$

Hand in hand with this correctio movement was the Carolingian court's ever-growing concern for the establishment of the right order, the idea that

4 Ganz, "Visions of Carolingian Education"; Van Rhijn, "Priests and the Carolingian Reforms".

5 Schramm, "Karl der Grosse"; Reuter, "Kirchenreform und Kirchenpolitik", 40-42. For a long-term study on the dynamics between monastic reform, the context within which this occurred, and its subsequent representation, see for example, Vanderputten, Monastic Reform as Process, esp. 1-14. On the use of the concept of "reform" by medieval and contemporary scholars, see also Barrow, "Ideas and Applications of Reform".

6 De Jong, Penitential State, 142-47; on the competitive atmosphere at the Carolingian court, see, for example, Tignolet, "Jeux poétiques".

7 Airlie, "Carolingian royal authority", 233, describes the court as a "frame of mind".

8 See, for example, Wickham, Inheritance of Rome, 405-26.

9 Garipzanov, Symbolic Language, 5-6; MacLean, Kingship and Politics, 144-45; Nelson, "Kingship and Empire".

10 On the role of the court as the primary tool for providing guidance to the Christians in the empire, see De Jong, "Sacrum Palatium". 
society ought to be organized in such a way that everybody knew his or her place in the greater scheme of things, and, importantly, would be satisfied with their lot. Given the sheer size of the Frankish realm, it was simply vital to have a well-ordered society in order for the "Carolingian experiment" to work." Moreover, the Carolingian elites contended that one could not have a properly functioning hierarchy if its order were not supported by everybody who was part of it. ${ }^{12}$ This had an impact on the perception of both teaching and learning. The authority of teachers hinged not only on their knowledge, but also on their students' willingness to actually learn from them. Concurrently, an idea that a symbiosis existed between power, responsibility, and knowledge was embedded in the Carolingian conception of how society worked: the more you knew, the more social power you could have, and the more powerful you were, the more knowledge you should possess. ${ }^{13}$ Taken together, this was a societal model that is called the ecclesia, in which religion, politics, ideology, and power all acted in close concord for the greater good. ${ }^{14}$

Monasteries played a crucial role in the development and propagation of these ideals. The many religious communities that dotted the Frankish ecclesiastical landscape fulfilled several important functions, the most important of which was to harness the "power of prayer" of the monks and nuns residing there. ${ }^{15}$ These people, who had dedicated their lives to the service of God, were given the task of interceding on behalf of those who were not in a position to do so directly, and as such it was up to them to ensure that their prayer duties were satisfactorily performed. To that end, they would congregate in communities that were, in theory, isolated from the world, and aspire to live the perfect Christian life in accordance with the monastic rules that governed their daily routine - chief among them the Rule of Saint Benedict, which had come to be propagated as the best of the monastic options available at the time. ${ }^{16}$ As written in that Rule, one of the most important tools for monks to perform their function in the ecclesia was to learn and to keep learning to the point

\footnotetext{
11 A point made, among others, in Nelson, "Kingship and Empire", esp. 220-23.

12 Depreux, "Hiérarchie".

13 Mann, Social Power, 376-90; Steckel, Kulturen des Lehrens, 123-24.

14 De Jong, "State of the Church", and by the same author, "Sacrum Palatium", esp. 1246. Given its emphasis on a shared cultus divinus among the believers, coupled with the strong sense of hierarchy implicit in the concept, the Carolingian ecclesia should not be confused with the ideas of the populus Christianus or the umma described in this volume by Heydemann and Lohlker respectively.

15 De Jong, “Carolingian Monasticism”, esp. 651.

16 Diem, "Inventing the Holy Rule".
} 
where they would have internalized the tenets of their faith, ensuring that their prayers would be as effective as possible. ${ }^{17}$

Conversely, it was up to the court to ensure that the monks and nuns were in a position to do so. Charlemagne's father and grandfather had already established a system of support for the larger monasteries in their realms, primarily through land grants and other economic means. ${ }^{18}$ Charlemagne and his son would continue this tradition, and even extend the immunities granted to monastic communities until they became veritable enclaves within the empire, answerable only to the court. ${ }^{19}$ Monasteries, in return, were expected to support the empire, sometimes materially, but mostly by liturgical means or by acting as outposts of Carolingian culture in recently conquered areas. ${ }^{20}$ They were expected to take the liberty granted by them through imperial support to become examples to their surroundings, and lift up the ecclesia in the process. So it was that in the course of the 8th and early gth centuries, court and cloister became inextricably intertwined in a mutually interdependent relation, and that correctio and monastic culture also became bound up with one another. ${ }^{21}$

This cooperation depended to a large extent on the willingness of those who had opted for a monastic life to participate, even if this meant changing their political allegiance, or forsaking traditions that they might have held on to for centuries if they clashed with the ideals propagated from the court. ${ }^{22}$ It also engendered an interesting paradox of Carolingian monastic life: in order for monasteries to persist as theoretically isolated enclaves, they had to come to terms with the fact that they needed to articulate their function as a part of the Carolingian world as a whole.

As demonstrated by Christina Lutter in this volume, one of the main ways in which a monastic community could persist in the face of the outside world was a strong sense of discipline. This paper will highlight another strategy of self-articulation, employed in several monastic narratives. In fact, the tools to develop this strategy were provided by the very institution that caused the paradox in the first place: the Carolingian empire itself. Thus we will take a

17 Regula Benedicti 73, ed. Lashofer et al., 294-97. For a contemporary reflection on this idea, see also Smaragdus, Diadema Monachorum, c. 100, ed. Migne, cols 689A-69oA.

18 Semmler, "Pippin III"; Dierkens, "Politique Monastique".

19 Kölzer, Urkunden, 27-29; Semmler, "Benediktinische Reform und kaiserliches Privileg".

20 Demonstrated most clearly in the Notitia de Servitio Monasteriorum, ed. Becker, pp. 48399; see also Wagner, "Zur Notitia de Servitio Monasteriorum".

21 Fried, "Der karolingische Herrschaftsverband".

22 Cf. for example Kramer, "Représentations de l'Autorité Impériale”. 
closer look at three stories that stand out in that they present instances where empire and monastery overlapped in a way that clashed with the "classic" image of monastic isolation. The first two texts, from the first half of the gth century, describe rulers and communities that were alive and well at the time they were composed, and reflect upon a situation their authors could see unfolding as they wrote. The third narrative, written much later, takes a more nostalgic turn and looks back to the time of Charlemagne in order to teach its audience a valuable lesson. Taken together, however, their juxtaposition allows us not only to see various strategies as to how and why monasteries in the Carolingian age established themselves as spiritual communities connecting the various levels of community within Carolingian society. They also show the entanglement of political and religious ideologies in the 9th century, and, consequently, how one of the tools used by monasteries to delineate their sphere of influence was to allow someone-but not just anyone- - to cross into their territory and provide them with the instructions they needed to prosper in their role. ${ }^{23}$

Monastic authors were aware of the existential difficulties caused by the cooperation between their community and the empire. Ideally, the communities they represented had been founded in splendid isolation far away from civilization. They were devoted solely to the spiritual and intellectual pursuits of their inhabitants, the intention being to isolate their inhabitants from worldly concerns so that they could focus all their energy on living the perfect Christian life in the seclusion provided by the walls of the cloister. ${ }^{24}$ Many medieval monasteries broke this stereotype and became powerful economic or political institutions in spite of themselves. Still, it remained an influential vision of monasticism, and continued to make its mark on the self-perception of the people living in these communities. ${ }^{25} \mathrm{~A}$ considerable part of their textual output was concerned with providing a justification as to why the

23 Lutter, "Affektives Lernen" shows how a comparable situation persisted in the High Middle Ages, while also showing how gender did not necessarily stand in the way of this relationship between court and cloister. For the purposes of this article, questions of gender have been left out of the equation: given that they are all written within a predominantly male environment, the chosen anecdotes do not touch upon issues relating to gender (either masculinity or femininity). On this topic, see, among others, Diem, "Gender of the Religious".

24 Hildebrandt, External School, 21-37; De Jong, "Carolingian Monasticism", 627-29; Raaijmakers, Making of Fulda, 28-30.

25 Mulder-Bakker, "The Invention of Saintliness"; for a general methodological overview of how to deal with this genre of texts, see Dubois and Lemaitre, Hagiographie Médiévale, or Sot, Gesta Episcoporum. 
community had sprung into existence in the first place, and subsequently how its founders had managed to consolidate its position as the religious and intellectual powerhouse in the area. ${ }^{26}$ They were not content to let the production of religious manuscripts, their role as advisers to rulers or the development of surrounding lands speak for themselves. Such was the power of their prayer, these authors believed, so strong were the constant aspirations of perfection, the drive to create a piece of heaven on earth, that they represented themselves as primarily concerned with exemplary lives so that the brilliance of their community would radiate outwards. From their vantage point, members of the early medieval monastic elite thus helped shape the idea of "enclaves of learning" through their actions as much as through their self-promotion. ${ }^{27}$

Composing hagiographical narratives served a very clear purpose for the consolidation of a community from within. They would furnish the inhabitants of a monastery with a common past and a common vision of the life they should all aspire to, for instance. Moreover, many of these texts were also part of a larger discourse, meant to show their intended audience that monasteries retained their place in the ecclesia. ${ }^{28}$ This was expected of them at the time. From the shared practices and cooperation implicit in the Carolingian conceptualization of the ecclesia, it logically followed that monastic communities should play to their strengths, which meant setting the standard as to what exactly constituted a perfect life. They were enabled to do this by their supporters, but it was up to them to live up to the great expectations placed on their shoulders.

\section{A Leading Emperor? The Sacred Foundations of Inda}

It was against this background that Louis the Pious made his way to Aachen early in 814 , to continue in the footsteps of his father. One of the most visible effects of his aspirations was the organization of an almost continuous series of councils at the imperial palace. Under the aegis of the emperor, who "had

26 See Pohl, "History in Fragments", for one such case-study in which a monastery employed its textual prowess as a "troubled and [...] desperate attempt to make ends meet in the light of adversity and controversial debate".

27 See also Faure, Visions of Power, 194-95, who describes Buddhist monasteries (in Japan) as "a closed space, an enclave of the cosmos within the surrounding chaos [...] a living organism, a utopia, a microcosm sufficient unto itself" - a description with which many a Carolingian monk might agree.

28 As shown for example in the case of Redon by Smith, "Aedificatio Sancti Loci". 
the most ardent zeal for divine worship through the inspiration of Heaven", several lengthy capitularies were issued from these gatherings of bishops and abbots between 816 and 819, striving to ensure that "many useful and necessary measures were taken with care and diligence for the improvement (emendatio) of the holy Church of God". ${ }^{29}$ In the process, Louis the Pious also took care to restructure his court, and replaced several key members from his father's entourage with his own trusted advisers. ${ }^{30}$ Among these was Benedict, founding abbot of the monastery of Aniane close to the city of Montpellier. The son of a local nobleman, Benedict underwent an epiphany as he approached adulthood, and opted for a monastic instead of a courtly life. As Aniane, the monastery he subsequently founded on his father's land, grew in size and importance, he also became an influential figure on the local scene, attracting the attention of many intellectuals in the empire, and eventually becoming a valued player at the Carolingian court. ${ }^{31}$

Ardo, who composed the hagiographical account of Benedict's life, the Vita Benedicti Anianensis, shortly after the abbot's death in 821 , went to great lengths to portray this ascent through imperial ranks as being an almost inevitable function of his increasing holiness: as Benedict learnt more and more about the proper monastic way of life, he also became a better Christian and thus better able to advise the ruler than some of his more worldly colleagues. ${ }^{32}$ This in turn led to something of a crisis of conscience. As outlined by Ardo, Benedict had started his monastic career in order to flee the intrigues of the Carolingian court. However, this should not mean he no longer needed to be obedient to the emperor. Obedience was, after all, one of the cornerstones of the monastic ideal that he strove to emulate-why should this be any different for the ecclesia within which these monasteries were to function? ${ }^{33}$

As represented in the Vita Benedicti Anianensis (VBA), Louis the Pious seems to have appreciated the ensuing tension as well. Thus, although he bade the abbot to move from his community in the south to the palace in Aachen, it also "pleased him [Louis] to provide him [Benedict] with a convenient place not far from the palace", so that he would have the abbot at his beck and call. Moreover, the text continues, Louis "decreed that thirty monks should dwell there in the service of Christ", which in turn prompted the abbot to "command brothers

29 Institutio Canonicorum, prologus, ed. and trans. Bertram, pp. 96 and 133.

$30 \quad$ Scharer, “Charlemagne's Daughters"; De Jong, Penitential State, 19-24.

31 Semmler, "Benedictus II", but cf. also Geuenich, "Kritische Anmerkungen”.

32 Ardo, Vita Benedicti Anianensis, ed. Kettemann, Subsidia Anianensia, pp. 139-223.

33 De Vogüé, "Structure et Gouvernement"; Noble, "Monastic Ideal"; on the later medieval situation, see also the contribution by Lutter in this volume. 
selected from noted monasteries to come", where "he might instruct them by his example to be lessons of salvation to others". ${ }^{34}$ It is the interaction between cloister and court in a nutshell, from a monastic perspective: the emperor ensured the existence of the monastery as an enclave unto itself by providing it with land and immunities, while the designated abbot took care of the education of the monks living there. Moreover, the monks chosen to live in Inda were expected to pass on what they had learned once they had fully internalized Benedict's teachings, thus spreading them across the empire. Ardo wanted to show that Benedict truly was involved in "the direction of the realm", working together with the ruler to give advice to everyone. ${ }^{35}$ His abbacy was not limited to Inda, but the emperor had indeed "set him over all monasteries in his realm" by making him the teacher of the ever-changing community founded so close to the centre of the empire. ${ }^{36}$

Ardo wrote from a monastic perspective, with a view to presenting his protagonist as a veritable holy man, a teacher to those who constituted his intended audience. ${ }^{37}$ Although he wanted his work to be read at court as well and possibly to establish a cult around Benedict, he did not claim to speak to the empire in its entirety. ${ }^{38}$ Another narrative of the foundation of Inda, however, presents an altogether different perspective, allowing us to add some nuance to this vision of monastic communities and their function in the greater scheme of things. This is the Carmen in Honorem Hludowici, a panegyric written in the later 820 s by a certain Ermold, known as Ermoldus Nigellus ("the Black"). ${ }^{39}$ Ermold was courtier of one of Louis' sons. He had been exiled for unclear reasons and was attempting to get back into favour with his erstwhile patron. One of the tools he employed to that effect was to compose a poem in honour of Louis, expressing the hope that the emperor's intercession might alleviate his punishment and allow him to go back home. Unwilling to take half-measures, Ermold ended up writing four books of poetry, praising almost every aspect of the imperial reign thus far, from Louis' youthful exploits to his building programme, and from his martial prowess to his piety. ${ }^{40}$

\footnotetext{
34 Ardo, Vita Benedicti Anianensis 35, trans. Cabaniss, p. 243.

35 Ardo, Vita Benedicti Anianensis 35, trans. Cabaniss, p. 244.

36 Ardo, Vita Benedicti Anianensis 36, trans. Cabaniss, p. 244.

37 Claussen, "Benedict as Teacher".

38 Kettemann, Subsidia Anianensia, 71-74; Ardo, Vita Benedicti Anianensis, praefatio, ed. Kettemann, pp. 140-43.

39 Ermoldus, Carmen, ed. and trans. Faral, pp. 2-200.

40 Depreux, "Pietas".
} 
The foundation of Inda occurs at the culmination of the second book, which details Louis' first steps as an emperor. After his father's death, Louis started on a tour of his empire, visiting all the important holy places so that his reign would have an auspicious start. Having arrived in Aachen, he was confirmed by Pope Stephen IV in a highly ordered ceremony, which, according to Ermold, concluded with a lengthy, sermon-like speech to everyone present. "May the holy rule of the fathers regulate the life of the clergy, and may the venerable law of our fathers bring our people together. May the order of monks increase in the teachings of Benedict; may it seek by the character of its life the holy and heavenly pasture", Ermold has Louis proclaim, before affirming his status as "ruler of the Christians", protector of the faith for which Christ had shed His own blood. ${ }^{41}$ Deftly weaving together biblical, antique and contemporary motifs, one of Ermold's goals here was to demonstrate not only that the Carolingians had indeed provided the best possible ruler, but also that they were constantly reminded (and reminding themselves) of their duty to bear the responsibility of the ecclesiastical correctio that characterized their reign. ${ }^{42}$

At this point, Ermold tells the story of Inda's foundation and its role as the eye in the storm of Louis' correctio. While the emperor's messengers were sent out to investigate "the canonical flock, both men and women, who live in holy fortresses", he himself established a monastery close to him, to serve as Benedict's headquarters. ${ }^{43}$ Louis got rid of all the wildlife in the area, rendering it unsuitable for hunting - that favourite pastime of the ruler and his courtiers-while simultaneously making it "pleasing to God".44 Benedict of Nursia's Regula flourished in this subdued wilderness, and Benedict of Aniane, "who was everything to everyone", became the "father" of the community. 45 The emperor, however, was never far away either, as Ermold elaborates on the "imperial custom" mentioned in Inda's foundation charter. ${ }^{46}$ Louis "stayed there often and came frequently to see the sheepfold; he took care of the expenses and supplied big gifts". ${ }^{47}$ In short, he was "at once caesar and abbot" caesar et abba simul. ${ }^{48}$

\footnotetext{
41 Ermoldus, Carmen, 2.954-57, trans. Noble, p. 149.

42 Bobrycki, "Self-promotion, Self-suppression".

43 Ermoldus, Carmen, 2.1161-65, trans. Noble, p. 154.

44 Ermoldus, Carmen, 2.1242-45, trans. Noble, pp. 155-56. Cf. Verdon, "Recherches sur la chasse"; Diesenberger, "Bausteine der Erinnerung", 6o-61.

45 Ermoldus, Carmen, 2.1246-48, trans. Noble, p. 156.

46 Stengel, "Immunitätsurkunde", 390-93. The "imperial custom" (mos imperialis) seems to refer to the donation of land specifically.

47 Ermoldus, Carmen, 2.1250-51, trans. Noble, p. 156.

48 Ermoldus, Carmen, 2.1249, ed. Faral, pp. 96-97.
} 
Compared to the description given in the Vita Benedicti Anianensis, Ermold seems more insistent on the abbatial role of the emperor. However, whereas Ardo's narrative included several anecdotes in which Louis took an active interest in communal living — and dying - Ermold simply showed the emperor as a teacher of the ecclesia in its entirety. ${ }^{49}$ For Ardo, Inda was a pretext for Benedict to go to Aachen, whereas Ermold treated the new foundation as a monastic extension of the emperor's teaching. In both cases, the wording and the description of the relationship between Benedict and Louis seems deliberately ambiguous, attesting both to the actual importance of the abbot's idea(l)s and the dynamic, productive and educational relationship between court and cloister.

Both Ardo and Ermold stopped short of showing Louis as actually being a teacher to his monks. To them, he was a leader, at the top of the Frankish hierarchy, charged with exercising God's will for the benefit of all. To fulfil this duty, he had to choose the best people available to help him carry out his responsibility, and Benedict was simply one of these people. However, sometimes the system would break down despite the ruler's best efforts, calling for him to play a different role altogether. It is to such a scenario that we now turn, as we will see Louis directly intervening in a conflict within a monastery before the situation truly got out of hand.

\section{A Preaching Emperor: Louis the Pious in the Vita Aegil}

This situation was described in another idealized narrative, composed sometime between 822 and $845-$ most probably around 840 , near the end of the abbacy of Hrabanus Maurus, who died in 842, well after the resolution of a political crisis that had held the elites of the realm in its grip between 829 and $833^{50}$ In a way, this crisis marked both the high and the low points in the Carolingian ecclesiastical system. On the one hand, the empire came to the verge of imploding when a combination of questionable political decisions, filial discontent over Louis' inheritance, and turmoil within the elite itself brought two opposing Frankish armies into the field, and led to the deposition and public penance of the emperor in $833 .{ }^{51}$ On the other hand, however, outright war was prevented, Louis underwent this penance more or less

\footnotetext{
49 In this he would be comparable to the ideal of the Zaydi imams, as described by Hovden in this volume. See also Cornell, Voices of Islam, 240-42.

50 Raaijmakers, Making of Fulda, 237-40.

$5^{1}$ De Jong, Penitential State, 38-50.
} 
voluntarily, and the bishops overseeing the ritual (as well as the reconciliation several months later) were still fully supportive of the very system that had almost brought about its own downfall. If anything, they had shown that everybody was subject to this self-imposed ideal of society-which was de facto seen as being divinely approved - and that ecclesia and empire had come out even stronger. ${ }^{52}$ Still, the seeds of discord had been sown, and came to a head once again in 841 , when the Battle of Fontenoy pitted the sons of Louis the Pious against each other as part of a bitter struggle for empire. ${ }^{53}$

In part, the Vita Aegil, composed by Brun Candidus, a monk of the monastery of Fulda who had lived through these events, was a product of these machinations. As one of the largest monastic communities in the empire, Fulda was, after all, a major player at the highest political level, as well as a powerful intellectual and economic force in the region. ${ }^{54}$ The protagonist of this hagiography, the abbot Aegil, had died in 822, but it had taken Candidus another 15 to 20 years to finish his work about the life of his teacher. In the meantime, Fulda had lived through a lengthy conflict itself as well, catalysed by the erection of a large and prestigious church in the monastery.

The construction of this building had already started under Aegil's predecessor, Ratgar, who had been accused by the monks of pursuing an all-tooambitious building programme. ${ }^{55}$ Although nobody seems to have disobeyed him directly, the dispute escalated in 812 , when the monks aired their grievances in the Supplex Libellus, a letter to Charlemagne asking him to intervene on their behalf. ${ }^{56}$ As the monks implied, Ratgar had started building this church not for the glory of God, but for his own prestige — and that ran counter to the monastic ideal of the time. The conflict lasted until the start of the reign of Louis the Pious, and ended with the deposition of Ratgar in 817, at which point Aegil took over. Peace had been restored, and the construction of the church continued, albeit at a more moderate pace. ${ }^{57}$

In spite of this benevolent interference, the community was left reeling in the wake of the conflict, and it must have left a deep impression on Candidus. As such, this conflict and the controversial circumstances under which Aegil had become abbot form the background of the entire work. The author had deliberately used it as a counterpoint to the ideal community that had been

52 Nelson, "Last Years"; Kramer, "Justified and Ancient".

53 Goldberg, Struggle for Empire, 101-05.

54 Candidus, Vita Aegil abbatis Fuldensis, ed. Becht-Jördens.

55 Raaijmakers, Making of Fulda, 99-131.

56 Semmler, "Studien zum Supplex Libellus".

57 Raaijmakers, Making of Fulda, 132-74. 
established by his protagonist. "Let the reader not consider the frequent reference to this unrest to be slanderous", he wrote-to him, he was not simply continuing a (now mostly lost) chain of hagiographical narratives that told the lives of all the abbots of Fulda; he was also recording past calamities in order to edify his future audience. ${ }^{58}$

The Vita Aegil was a production in two parts-a so-called opus geminum. ${ }^{59}$ One of the parts took the form of a long poem which was meant to convey to the monks of Fulda the idea that their church should be seen as a symbol of the ecclesia and the tradition for which they stood. ${ }^{60}$ Conversely, the prose part was a didactic text in the best tradition of Carolingian hagiography, aiming to provide "a monastic programme in prose", painting the picture of an ideal monastery for a rather broad audience. ${ }^{61}$ This was, after all, part of a communal tradition, and even though Aegil was not the founder of the monastery, he had guided the community through a severe existential crisis. In a sense, he had re-founded the monastery on a sturdy Carolingian base. For Candidus, composing the narrative the way he did thus not only aimed at re-establishing a sense of togetherness within the community, but also showed the outside world that Fulda was back and ready for action.

Curiously, a centrepiece of this edification was a sermon — not by the abbot or high-ranking prelate, but by the emperor himself. ${ }^{62} \mathrm{He}$ delivered this speech to a group of monks who had come to ask him to arbitrate in their conflict. ${ }^{63}$ Louis obliged, but not before admonishing the monks that they ought not to have let it come this far. The problem, he told them, was not only the abbot himself, but also the fact that the monks, in spite of their learning, had diverged from the right path, letting go of the Rule and their discipline simply because they felt compelled to do so by one man. "After all, brothers", he berated them, "you have knowledge of Divine Scripture; you have the examples of the holy fathers who have preceded you, and you have a Rule instituted especially for you. In all these you can without doubt observe yourselves as if looking in a mirror, what you are and what you strive to become". ${ }^{64}$ In spite of all that potential, the monks had strayed from the right path, and thus proven

$5^{8}$ Candidus, Vita Aegil 24, ed. Becht-Jördens, p. 19. This was a common enough reason for recording such episodes in a community's history: Booker, "New prologue", 91.

59 Walter, Opus Geminum, 57-66.

6o Raaijmakers, Making of Fulda, 143-44.

61 Raaijmakers, Making of Fulda, 243-57.

62 Candidus, Vita Aegil 9-10, ed. Becht-Jördens, pp. 9-13, or about 25 per cent of the total length.

63 A similar situation is described in Frotharius, Epistola 21, ed. Hampe, p. 291.

64 Candidus, Vita Aegil 9, ed. Becht-Jördens, p. 9. 
themselves to be unable to live together in love and concord. That, Candidus impresses upon his audience, was why their new church was simply an opulent building and not a House of God. As Louis concluded, "people live in buildings, but God lives in holy people". ${ }^{65}$

It is doubtful that Louis the Pious ever actually delivered a sermon of this scope and magnitude. Even if it is clear that the Carolingians, like many rulers in the Early Middle Ages, would frequently visit large monasteries on their travels, it seems more logical that they did so as part of their travels, not to quell a specific conflict in a specific community-important though it might be. ${ }^{66}$ Similarly, it should not be forgotten that there are indications that the real Ratgar, though controversial, was not the bad abbot represented in the vita of his successor: Candidus clearly intended to use him as an exemplary bad abbot, a foil to the idealized abbacy of Aegil, which would have influenced his portrayal of Ratgar. ${ }^{67}$ In fact, Ratgar himself had probably been the subject of a hagiographic narrative as well, having been part of the monastery's communal history and identity despite the dispute surrounding his new church. 68

Instead, the inclusion of this story should be seen as a claim on the nature of imperial authority and its impact on the self-assertion of a monastic community faced with the reforms proposed by the court. It was a community in search of itself after a rather severe crisis of identity. Brun Candidus deemed it best to convey the moral admonitio he wanted to impress upon his audience not by means of the abbot whose life he was narrating, but through an actor who was an integral part of the ecclesia without being part of the smaller monastic world of Fulda. The emperor in this story had assumed an idealized persona, akin to the caesar et abba simul described by Ermold or, using a formulation that recurred more often in the Carolingian discourse, a rex et sacerdos, a "king and priest" who represented both the worldly and the spiritual leadership of the Christian world. ${ }^{69}$ Candidus's emperor was able to transcend the boundaries of theoretically closed-off monasteries and to help them acquire the knowledge they needed to strengthen their sense of community. ${ }^{70}$

\footnotetext{
65 Candidus, Vita Aegil 10, ed. Becht-Jördens p. 12. See also Nelson, "Cour Impériale".

66 McKitterick, "A King on the Move".

67 Raaijmakers, Making of Fulda, 259-63.

68 Although many such vitae from Fulda are now lost, an example of such a monastic serial hagiography may be found in the Gesta Abbatum Fontanellensium, ed. Pradié, from SaintWandrille. Cf. Howe, "Hagiography of Saint-Wandrille", 128-29 and 190-91.

69 Angenendt, "Rex und sacerdos".

70 De Jong, Penitential State, 133.
} 
In the story of Fulda, Louis' sermon was the catharsis of a conflict that had lasted over a generation.

The imperial sermon occurred at a time when it was acceptable to identify the ruler, the imperial court of the Carolingians, as a source of wisdom, a place from which the monks of Fulda might receive guidance that would strengthen their monastic ideology — both the "internal cloister" of each individual monk residing there, and their community as a whole. ${ }^{71}$ The fact that this Louis was most likely a literary construct, and that the anecdotes themselves had little to do with what actually happened, is beside the point: if hagiographical narratives were expected to describe ideals, we cannot blame the authors for describing what they considered an ideal situation — within the boundaries of what their intended audience would expect, of course. To Candidus, the allinclusive vision of community propagated by the court was strong enough to allow the walls of the cloister to be breached, and even to admit that not all was well within the community until the emperor came and set things right. From his position on top of the ecclesia, an intermediary between God and the people, he was in a prime position to do so. Candidus' emperor was not angry—just disappointed.

For the author of the final narrative treated in this article, mere disappointment was not enough. Jumping forward another 50 years, to the end of the 9 th century, and to yet another monastic community, we will now turn to a text that does not show an emperor acting within a monastery-it attempts to describe how a ruler ought to behave in his own court.

\section{A Teaching Emperor: Charlemagne in Notker's Gesta Karoli}

Thus far, the texts under scrutiny have described situations that were fairly close to both author and intended audience. Our next text takes a wholly different approach. Written sometime around $885^{-6}$ by Notker the Stammerer, a monk of the monastery of Sankt-Gallen, the Gesta Karoli present a vision of past circumstances in order to entice the audience to recreate the former

71 Perhaps the clearest example of the idea that the court was a source of divine wisdom may be found in the prologue to the Vita Benedicti Anianensis, where Ardo describes the palace as providing a "flow of wisdom from an unfailing watercourse of the purest fountain", 142, echoing Sir. 1:5. See also De Jong, "Internal cloisters", as well as Breitenstein, "Verantwortung als Ziel der Gewissensbildung" for an example of a similar mentality in the High Middle Ages. 
glory described. ${ }^{72}$ More specifically, it concerns a narrative about the deeds of Charlemagne, dedicated to his great-grandson, who was also named Charles (nicknamed "The Fat"). Far from being a biography stricto sensu, however, the work reads like a series of anecdotes that are difficult to place chronologically. ${ }^{73}$ What is clear is that most of the stories related had a predominantly literary character and were based around Charlemagne's towering reputation rather than his actual life story. Nevertheless, their sequence gives us an impression of this one monk's advice to the court, using the memory of Charlemagne, combined with his own wit, to educate the current generation of rulers on how to improve the state of affairs. ${ }^{74}$

Time had not stood still since the death of Louis the Pious in 840. By the time Notker was active, the Carolingian Empire had endured political crises, division and even civil wars. It had quelled heresies. It was threatened on all sides by invasions by Vikings, Hungarians and Saracens, but it had persisted, and its elites had tenaciously clung to the ideal of cultural and religious improvement as best as they could..$^{75}$ Nevertheless, it had become clear that the empire was shaking at its foundations. The momentum generated by Charlemagne and his heir had been dampened, and the fact that Charles the Fat had failed to produce a suitable heir led many to fear that the dynasty was about to come to an end. In this climate, Notker took it upon himself to remind people of the greatness that once was-to remind the current emperor of the deeds that had made his great-grandfather "Great". ${ }^{6}$

For its part, the monastery of Sankt-Gallen weathered the times as best as it was able. A large, powerful institution with a tradition stretching back to pre-Carolingian times, it had been founded in its current incarnation in 719 by Othmar, reputedly on the site of the cella of an Irish monk, Gallus, who was believed to be one of the 12 companions of the 6th-century missionary Columbanus. By the gth century, the community had grown into one of the most influential monasteries of the empire, and was sponsored by local nobility and imperial court alike. ${ }^{77}$ Its library and extensive collection of original charters and other manuscripts stand as a testament of its achievements even

72 Notker, Gesta Karoli, ed. Haefele, p. 1-93; MacLean, Kingship and Politics, 201-04.

73 Goetz, Strukturen der spätkarolingischen Epoche, 4-8.

74 Ganz, "Humour as History".

75 Costambeys et al., Carolingian World, 379-426.

76 MacLean, Kingship and Politics, 199-229.

77 Cf. Zettler, "Bischofs- und Königskloster". A charter from 881 even refers to the same "imperial custom" as in the case of Inda: Karolus III, Diploma 38, ed. Kehr, p. 65. On the charters as a reflection of the community's relation to the empire, see furthermore, Zeller, "Karolingisches Imperium und regionales Urkundenwesen". 
today. ${ }^{78}$ From the community's — or rather, Notker's — vantage point, they, as guardians of knowledge, tradition and the proper way of life, were in a perfect position to educate the current ruler and his court. ${ }^{79}$

The opening chapters of the work are telling in this regard, as they are set right at the start of Charlemagne's reign, at a time when "the study of letters was almost everywhere forgotten, and even the worship of the true God had become tepid". ${ }^{80}$ Just then, two monks arrived from Ireland, offering to teach anyone who would accept their wisdom. At first, things did not go well. They even had to go to a marketplace and pretend "that they had wisdom for salebecause they saw that the people had come to trade what was for sale, not what was for free". ${ }^{81}$ Their cries eventually reached the ears of Charlemagne, who asked them the price of their teaching - to which they promptly responded that they only wanted "suitable dwellings and eager minds, food and clothing, for without these things our mission cannot be completed". ${ }^{82}$ What they needed was an enclave where they could devote their time to studying and teaching without being fettered by worldly concerns. They asked the emperor to take care of their earthly needs, so they could set their sights to a higher purpose.

Given Notker's own background, it seems obvious that he envisaged this to be a monastery - and this was an idea that would have resonated with his peers, given the importance of monasteries in the Carolingian correctio. To sponsor a monastery was to live up to the expectations of the Church. Establishing such educational ventures was about more than teaching people to read and write-it was about spreading wisdom throughout the empire.

As such, it is not surprising that Notker's Irish monks also asked Charlemagne to provide them with "eager minds" to teach. This the emperor did. "He assigned to [Clement, one of the monks] many boys of the nobility, of the middling sort, and of the lower classes" to educate, while he went off to deal with "urgent military affairs" ${ }^{83}$ After a short intermezzo where Notker describes the arrival of Alcuin of York, yet another insular scholar with an impressive pedigree of learning, ${ }^{84}$ the story continues when Charlemagne returned victorious and "ordered the boys whom he had commended to Clement to come to him

\footnotetext{
78 Geuenich, "Mönche und Konvent".

79 Siegrist, Herrscherbild und Weltsicht, 139-45.

8 o Notker, Gesta Karoli 1.1, trans. Noble, p. 59.

81 Notker, Gesta Karoli 1.1, trans. Noble, p. 59.

82 Notker, Gesta Karoli 1.1, trans. Noble, p. 60.

83 Notker, Gesta Karoli 1.1, trans. Noble, p. 60.

84 See Bullough, Alcuin, 17-34, on the life and posthumous reputation of this scholar.
} 
and to offer him their letters and poems"; they did so, and to his surprise "those of the middling and lower sort offered works adorned [...] with every sweet sign of wisdom, whereas the noble boys handed over flimsy works that were wholly silly". ${ }^{5}$

The ruler responded in kind. Invoking imagery from the New Testament, Notker casts Charlemagne in the role of the Divine Judge, and describes how he "set those who performed well at his right hand", commended them and admonished them to "be eager to do even better" so that they may eventually receive "bishoprics and splendid monasteries". 86 Then he addresses the ones on his left, and tells them off in a thunderous speech: "You nobles, you sons of magnates, you delicate and pretty boys, you who trust in your birth and wealth, setting aside my command and your own advancement, you neglected the study of letters, and you indulged in luxury, games, idleness, and useless pastimes". To make matters worse for them, Charlemagne then swears the following oath: "By the king of Heaven, I give no weight to your nobility and good looks even though others may esteem you. Know this beyond any doubt: unless you make up for your earlier negligence by diligent study, you will never obtain anything of value from Charles". ${ }^{87}$

It is the type of anecdotal example for which Notker was known. This was his ideal of the way the empire should be run: by well-educated people who continuously strove to improve their capabilities, not by people who were given power by virtue of their inheritance, or who were only out for their own advancement. ${ }^{88}$ Consequently, one of the main functions of monasteries, as far as he was concerned, was to improve the empire through the education of the aristocracy. ${ }^{89}$ As we have seen earlier, these enclaves of learning would be marked by their specialized function within the world, relying on the benevolence of the empire (or whatever sponsors they could find) to actually focus on fostering learning full-time. Although this ideal was never completely lost, Notker seems to have been nostalgic for an empire vital enough to bear that burden, in a climate that was increasingly veering toward monastic autonomy. ${ }^{90}$

85 Notker, Gesta Karoli 1.3, trans. Noble, p. 61.

86 See Mat. 25:31-46 and Rev. 20:11-15. This is not the only instance of eschatological imagery in Notker-see Latowsky, Emperor of the World, 38-43.

$87 \quad$ All quotations are from Notker, Gesta Karoli 1.3, trans. Noble, p. 61.

88 See Stone, Morality and Masculinity, 137-39.

89 Hageneier, Jenseits der Topik, 187-237, esp. 218.

$90 \quad$ Ganz, "Humour as History", 182; Hallinger, Gorze-Kluny; cf. also Vanderputten, Monastic Reform as Process, 79-101. 
Notably absent from Notker's ideal is an insistence on the purity of the teachings offered - one of the reasons behind the foundation of Inda, for example. The knowledge generated in Notker's school should of course hark back to the Bible and the wisdom of the Church Fathers, but was not defined by the community or its "spiritual master" per se. At the start of the story, the teachers who kick-started the renaissance of learning in the Frankish realms were outsiders, Irish monks - a logical choice, if Notker's ecclesia was based on the monastery he lived in. The anecdote then ends with the ruler himself berating some of the students (and by extension, their teacher) for not doing an adequate job. This Charlemagne, this literary creation of Notker's, wanted only the best for the management of his realm. For that reason he had to become both a judge and, in effect, a teacher, meting out punishment while also explaining his reasons for doing so. The students could obtain knowledge from anyone qualified to pass it on, but to learn about the empire, to learn about their place in the greater scheme of things, these fledgling functionaries needed guidance from outside.

This was perfectly acceptable to Notker-laudable, even. Given the circumstances under which he was writing and the intended audience of his work, he was describing a situation that he would like to be re-instituted, and it is tempting to think that he as an auteur used Charlemagne's persona to criticize some less-than-exemplary students in his own monastery. ${ }^{91}$ The model he advocated was one where monasteries could function as enclaves in a practical, material sense, but which would be integrated into the world-the Carolingian Church — in all other ways, be it spiritually, intellectually, or even politically.

\section{Learning Empire}

The Gesta Karoli described an idealized past, a longing for an ideology that Notker felt had been watered down over the generations. Ardo's Vita Benedicti Anianensis and Ermold's Carmen in Honorem Hludowici presented their audience with a vision of their communities-cloister and court respectivelyjust at the time when the grandest possible design for the empire was being implemented. Candidus, finally, also used Louis' role in the resolution of the conflict described in the Vita Aegil as a commentary on recent events, representing his community as a microcosm of the empire at large. Consequently,

91 Cf. Pizarro, "Images of Church and State", $35^{-36 .}$ 
the way each of the authors represented their rulers also differed; the emperor is a saint's adviser in one story, a bishop or preacher in the next, and an arbitrator or judge in another. More accurately, each of these roles overlap to a large extent-Louis' arbitration in Fulda is described in pastoral terms, for example, whereas Notker's angry schoolteacher is portrayed as a heavenly judge. Each different role thus reflected different facets of ecclesiastical authority, and the portrayals of Louis the Pious and Charlemagne in these stories actually demonstrate different interpretations of how one person would combine these requirements. Nonetheless, the rulers in these stories were significant for these communities, and their significance is expressed in terms of imparting knowledge (and the accompanying change of attitude), of strengthening a community through religious teaching, which in turn strengthened their discipline as well. ${ }^{92}$ The two terms were, after all, closely related: as Augustine had already pointed out in his De Disciplina Christiana, "Discipline comes from learning (disco), and the house of discipline is the Church of Christ (disciplinae domus est Ecclesia Christi)". ${ }^{93}$ Highlighting the multiplicity of learning, this also points out one basic characteristic that speaks volumes about the status of monastic communities within the wider Christian community of the Carolingian Empire. Learning or knowing the right way of doing things was not dependent on the isolation of the communities themselves, on the guidance provided by a codified set of rules. Far from it: in each of these stories, it was the Carolingian court, personified by the Carolingian ruler, which provided essential guidance on how to proceed-how to learn.

Carolingian correctio required people in key positions who could transcend the spiritual boundaries of their communities. ${ }^{94}$ They were to act as a conduit between the secluded world of the cloister and the wider world of the ecclesia. The ability to foster knowledge, internalize teachings, and acquire wisdom remained a prerogative of monks and nuns alike. They took recourse to the sacred texts at their disposal, and the traditions that had served them so well over the years, commented upon them and even added to them as they saw necessary. ${ }^{95}$ However, in order for the rest of the empire to profit from their

92 See also Lutter, "Vita Communis".

93 Augustinus, De Disciplina Christiana, 1, ed. Plaetse, p. 407 ; trans. Hill, p. $45^{8}$.

94 Semmler, "Zur verfassungsrechtlichen Einordnung"; Fichtenau, Das karolingische Imperium, 140-42.

95 As a prime example of how this was not just the prerogative of monks, the Annales Mettenses Priores, which were most likely composed at the nunnery of Chelles, provide an interesting alternative to the historiographical discourse current at the time, forming a distinctive piece of "pro-Carolingian propaganda" without losing the author's "distinctive voice": Hen, "The Annals of Metz". 
learning, they needed people who embodied the best of both worlds. Ideally, these would be the emperors themselves. ${ }^{96}$ As had been written in the name of Louis the Pious in 825 , "the sum of all responsibilities came together in the person of the ruler". ${ }^{97}$ According to the model developed by the Carolingians, it was the rulers who bore the ultimate responsibility for the well-being-both spiritually and materially — of every Christian within the empire. ${ }^{98}$ Thus it was equally important for them to be able to teach everybody as well, or at the very least they had to be able to teach the teachers, who would then be able to teach their students, and so on.

It is for this reason that it is deceptively easy to think about monastic communities in 9th-century Europe as being institutions quintessentially devoted to the fostering of knowledge specifically. By the time the Carolingian dynasty had taken power, monasteries had become firmly embedded within the apparatus of rulership. Once again, the keyword was interdependence. For the Carolingian court, establishing what exactly constituted a monastery and what would be its place in the ecclesia was something that followed from even grander imperial ideologies. For the monasteries themselves, presenting themselves as enclaves providing spiritual guidance within the empire meant buying into that Carolingian ideal. This could be profitable from a spiritual, but also from a material point of view: fully integrated communities were granted immunities more easily, and it would be more opportune for potential benefactors to associate with them, as this would not only net them saintly protection provided by the monastery, but also reveal them as supporters of the imperial court.

It was the insistence on the establishment of such a system which turned the Carolingian empire into an "imagined community", an ideological construct writ large, with all the dues and obligations that came with it. ${ }^{99}$ As presented in courtly sources from the later 8th and 9th centuries, the Christianization of the empire had developed to the point that it was difficult for monasteries to rely on their status as "Christian" institutions par excellence. Everybody would be part of the same system, and answerable to God in the end. Carolingian monasteries were not separate from the world around them, and came to be seen as the sacred foundations of the ecclesia. As a contemporary observer

\footnotetext{
96 Werner, "Hludovicus Augustus", 101-02.

97 Admonitio ad Omnes Regni Ordines 3, ed. Boretius, p. 303; Guillot, "Une ordinatio méconnue", as well as Hannig, Consensus Fidelium, 269.

98 Alberi, "Imperium christianum"; Van Espelo, "Testimony".

99 Anderson, Imagined Communities, 5-7.
} 
reminded the monks of the empire: "if the dwelling of one person is properly called a monastery [...] we must ask why the dwelling of many persons established in one place is also called a monastery, unless perhaps $[. .$.$] it is$ because there is one faith, one baptism, one heart and one soul [Eph 4:5] in all monks who are living good and upright lives, just as there was earlier in the religion of those who believed rightly and lived good lives".100 Carolingian monks strove to re-establish this "earlier religion" - starting with themselves, then within their own communities, and finally, in the world. To remain Christian communities in a Christian empire, these monastic communities could not afford to persist in their isolation. Instead, monasteries had to be the very best the ecclesia had to offer, and it did not matter who taught them as long as the teaching was sound. ${ }^{101}$ To retain their status as enclaves of learning, they had to allow some people to transcend their self-imposed boundaries and remind them of the importance of their mission. ${ }^{102}$ And if the emperor himself were not able to do this, then who would?

This offers an alternative to the strategies of distinction outlined in the other papers in this section of the volume. Compared to those cases, the Carolingian monasteries as presented in the chosen narratives were less concerned with marking boundaries using "learning" as a category. For them it was a tool to demonstrate how they, as a community, were integrated into a framework that expected them to put all their knowledge at the service of the ecclesia. They were not presented as vehicles for the more individualized education of (and by) venerable masters exclusively, as seems to have been the case for medieval Tibet, and neither was the uncorrupted teaching as passed on through an intellectual genealogy of abbots a conditio sine qua non for the consolidation of a communal identity. ${ }^{103}$ The monasteries in the Carolingian ecclesia were not strictly defined according to their heritage or the provenance of their members, as with the South Arabian hijras inhabited by the ashraf for example, or the Schottenklöster in high medieval Central Europe-Notker's description of the two monks as being Irish notwithstanding. ${ }^{104}$ Most importantly, the communal identity of these monasteries did not contradict the

\footnotetext{
100 Smaragdus, Expositio regulae Sancti Benedicti 3, trans. Barry, p. 154.

101 Cf. Bullough, "Kingdom of Heaven".

102 De Jong, "Sacrum Palatium", 1252-55.

103 See the contributions by Hugon, "Religious and Intellectual Communities", and Fermer, "Among Teachers" in this volume.

104 See the contributions by Hovden, "Competing Visions" (on the Yemeni hijra) and Ó Riain, "Schottenklöster in the World" (on the phenomenon of Schottenklöster), in this volume.
} 
mores of the larger social whole within which they functioned. ${ }^{105}$ Their exemplary function and the way in which they interacted with the world around them were not institutionalized, but represented the community's willingness to be exemplary. The monks that produced these narratives were aware of their role in the great Carolingian ecclesiastical correctio. They accepted that learning was not a strictly self-perpetuating endeavour, and they applauded initiatives from their rulers to enhance their qualitiesand mutatis mutandis, of all monasteries in the empire.

\section{Bibliography}

\section{Primary Sources}

Admonitio ad Omnes Regni Ordines, ed. Alfred Boretius, Monumenta Germaniae Historica (MGH) Capitularia regum Francorum 1 (Hanover, 1883), pp. 303-07.

Ardo, Vita Benedicti Anianensis, ed. and trans. Walter Kettemann (Duisburg, 2001), pp. 139-223; trans. Alan Cabaniss (Elms Court, 1979).

Augustinus, De Disciplina Christiana, ed. Roel Vander Plaetse, Corpus Christianorum

Series Latina 46 (Turnhout, 1969); trans. Edmund Hill (Hyde Park NY, 1995).

Candidus, Vita Aegil abbatis Fuldensis, ed. Gereon Becht-Jördens (Marburg, 1994).

Ermoldus Nigellus, Carmen in Honorem Hludovici Augusti, ed. and trans. Edmund Faral (Paris, 1932), pp. 2-200; trans. Thomas Noble (Philadelphia, 2009), pp. 127-85.

Frotharius, Epistolae, ed. Karl Hampe, MGH Epistolae 5, 1 (Berlin, 1898), pp. 275-98.

Gesta Abbatum Fontanellensium, ed. Pascal Pradié (Paris, 1999).

Institutio Canonicorum, ed. and trans. Jerome Bertram (Aldershot, 2005), pp. 96-131.

Karolus III, Diploma 3 , ed. Paul Fridolin Kehr, MGH Diplomata Karoli III, (Berlin 1937).

Notitia de Servitio Monasteriorum, ed. Petrus Becker (Siegburg, 1963), pp. 483-99.

Notker, Gesta Karoli Magni Imperatoris, ed. and trans. Hans Haefele, MGH Scriptores rerum Germanicarum N.S. 12 (Berlin, 1980); trans. Thomas Noble (Philadelphia, 2009), pp. 59-118.

Regula Benedicti, ed. Clemens Lashofer et al. (Göttweig, 1992).

Smaragdus, Diadema Monachorum, ed. Jacques Paul Migne (Paris, 1853), cols. 593-690.

Smaragdus, Expositio regulae Sancti Benedicti, ed. Alfred Spannagel and Pius Engelbert (Siegburg, 1974), pp. 3-337; trans. David Barry (Kalamazoo, 2007).

105 As opposed, for example, to the hijra of the Mutarrifyya Zaydis, the existence of which clashed with the established economic, political and religious powers in the region: see Hovden, "Competing Visions". 


\section{Secondary Literature}

Stuart Airlie, "For it is written in the Law': Ansegis and the writing of Carolingian royal authority", in Early Medieval Studies in Memory of Patrick Wormald, eds. Stephen Baxter, Catherine E. Karkov, Janet L. Nelson, and David Pelteret, Studies in Early Medieval Britain (Aldershot, 2009), 219-35.

Mary Alberi, "The evolution of Alcuin's concept of the Imperium christianum", in The Community, the Family and the Saint: Patterns of Power in Early Medieval Europe, ed. Joyce Hill, International Medieval Research (Turnhout, 1998), 3-17.

Benedict Anderson, Imagined Communities: Reflections on the Origin and Spread of Nationalism (London, New York, 1983).

Arnold Angenendt "Karl der Große als rex und sacerdos", in Das Frankfurter Konzil von 794: Kristallisationspunkt karolingischer Kultur. Akten zweier Symposien (vom 23. bis 27. Februar und vom 13. bis 15. Oktober 1994) anläßlich der 1200-Jahrfeier der Stadt Frankfurt am Main, ed. Rainer Berndt, Quellen und Abhandlungen zur mittelrheinischen Kirchengeschichte 80 (Mainz, 1997), 255-78.

Ovamir Anjum, Politics, Law, and Community in Islamic Thought: The Taymiyyan Moment, (Cambridge 2012).

Julia S. Barrow, "Ideas and applications of reform", in The Cambridge History of Christianity 3: Early Medieval Christianities, c. 6oo-110o, eds. Thomas F.X. Noble and Julia M.H. Smith (Cambridge, 2008), 345-62.

Shane Bobrycki, "Nigellus, Ausulus: self-promotion, self-suppression and Carolingian ideology in the poetry of Ermold", in Ego Trouble: Authors and their Identities in the Early Middle Ages, eds. Richard Corradini, Matthew Gillis, Rosamond McKitterick and Irene van Renswoude, Forschungen zur Geschichte des Mittelalters 15 (Vienna, 2010), 161-73.

Courtney Booker, "A new prologue of Walafrid Strabo", Viator 36 (2005), 83-105.

Mirko Breitenstein, “Der Traktat 'Vom inneren Haus': Verantwortung als Ziel der Gewissensbildung", in Innovation in Klöstern und Orden des Hohen Mittelalters: Aspekte und Pragmatik eines Begriffs, ed. Mirko Breitenstein, Vita Regularis 48 (Berlin, 2012), 263-92.

Giles Brown, "Introduction: the Carolingian Renaissance", in Carolingian Culture: Emulation and Innovation, ed. Rosamond McKitterick (Cambridge, 1994).

Donald Bullough, "Alcuin and the Kingdom of Heaven: liturgy, theology and the Carolingian Age", in Carolingian Essays: Andrew W. Mellon Lectures in Early Christian Studies, ed. Uta-Renate Blumenthal (Washington DC, 1983), 1-69.

Donald Bullough, Alcuin: Achievement and Reputation, Education and Society in the Middle Ages and Renaissance 16, (Leiden 2002).

Martin A. Claussen, "Benedict of Aniane as teacher", Discovery and distinction in the early Middle Ages: studies in honor of John J. Contreni, eds. Cullen J. Chandler and Steven A. Stofferahn (Kalamazoo, 2013), 73-87. 
Vincent Cornell, ed., Voices of Islam (Westport CT, 2007).

Marios Costambeys, Matthew Innes and Simon MacLean, The Carolingian World, Cambridge Medieval Textbooks, (Cambridge 2011).

Mayke de Jong, "Carolingian monasticism: the power of prayer", in The New Cambridge Medieval History II: c. 70o-c. 9oo, ed. Rosamond McKitterick (Cambridge, 1995), $622-53$.

Mayke de Jong, "Charlemagne's Church", in Charlemagne: Empire and Society, ed. Joanna Story (Manchester, 2005), 103-36.

Mayke de Jong, "Internal cloisters: the case of Ekkehard's Casus sancti Galli", in Grenze und Differenz im frühen Mittelalter, eds. Walter Pohl and Helmut Reimitz, Forschungen zur Geschichte des Mittelalters 1 (Vienna, 2000), 209-21.

Mayke de Jong, "Sacrum palatium et ecclesia: L'autorité religieuse royale sous les Carolingiens (790-840)", Annales: Histoire, Sciences Sociales $5^{8}$ (2003), 1243-69.

Mayke de Jong, "The state of the church: ecclesia and early medieval state formation", in Der frühmittelalterliche Staat: europäische Perspektiven, eds. Walter Pohl and Veronika Wieser, Forschungen zur Geschichte des Mittelalters 16 (Vienna, 2009), 241-54.

Mayke de Jong, The Penitential State: Authority and Atonement in the Age of Louis the Pious, 814-840, (Cambridge 2009).

Adalbert De Vogüé, "Structure et gouvernement de la communauté monastique chez Saint Benoît et autour de lui", in Atti del $7^{\circ}$ Congresso Internazionale di Studi sull'Alto Medioevo (Spoleto, 1982), 563-98.

Philippe Depreux, "La pietas comme principe de gouvernement d'après le Poème sur Louis le Pieux d'Ermold le Noir", in The Community, the Family and the Saint:Patterns of Power in Early Medieval Europe, eds. Joyce Hill and Mary Swan (Turnhout, 1998), 201-25.

Philippe Depreux, "Hiérarchie et ordre au sein du palais: l'accès au prince", in Hiérarchie et Stratification Sociale dans l'Occident Médiéval 40o-110o, eds. Dominique IognaPrat, François Bougard and Régine Le Jan, Collection Haut Moyen Âge 6 (Turnhout, 2008), 305-24.

Albrecht Diem, "Inventing the Holy Rule: some observations on the history of monastic normative observance in the Early Medieval West", in Western Monasticism ante litteram: The Space of Monastic Observance in Late Antiquity and the Early Middle Ages, eds. Hendrik W. Dey and Elizabeth Fentress, Disciplina Monastica 7 (Turnhout, 2011), 53-84.

Albrecht Diem, "The gender of the religious: wo/men and the invention of monasticism", in The Oxford Handbook of Women and Gender in Medieval Europe, eds. Judith M. Bennet and Ruth Mazo Karras (Oxford, 2013), 432-47.

Alain Dierkens, "Carolus monasteriorum multorum eversor et ecclesiasticarum pecuniarum in usus proprios commutator? Notes sur la politique monastique du maire 
du palais Charles Martel", in Karl Martell in seiner Zeit, ed. Jörg Jarnut, Beihefte der Francia 37 (Sigmaringen, 1994), 277-94.

Maximilian Diesenberger, "Bausteine der Erinnerung: Schrift und Überrest in der Vita Sequani”, in Vom Nutzen des Schreibens: Soziales Gedächtnis, Herrschaft und Besitz im Mittelalter, eds. Walter Pohl and Paul Herold, Forschungen zur Geschichte des Mittelalters 6 (Vienna, 2002), 39-66.

Jacques Dubois and Jean-Loup Lemaitre, Sources et Méthodes de l'Hagiographie Médiévale, (Paris 1993).

Bernard Faure, Visions of Power: Imagining Medieval Japanese Buddhism, trans. Phyllis Brooks (Princeton, 1996).

Heinrich Fichtenau, Das karolingische Imperium: Soziale und geistige Problematik eines Grossreiches, (Zürich 1949).

Johannes Fried, "Der karolingische Herrschaftsverband im 9. Jahrhundert zwischen 'Kirche' und 'Königshaus', Historische Zeitschrift 235 (1982) 1-43.

David Ganz, "Humour as history in Notker's Gesta Karoli Magni", in Monks, Nuns and Friars in Medieval Society, eds. Edward B. King, Jacqueline T. Schaefer and William B. Wadley, Sewanee Medieval Studies 4, (Sewanee, 1989), 171-83.

David Ganz, "Conclusion:Visions of Carolingian education - past, present, and future", in The Gentle Voices of Teachers: Aspects of Learning in the Carolingian Age, ed. Richard E. Sullivan (Columbus OH, 1995), 261-83.

Ildar H. Garipzanov, The Symbolic Language of Authority in the Carolingian World (c. 757-877), Brill's Series on the Early Middle Ages 16 (Leiden, 2008).

Dieter Geuenich, "Kritische Anmerkungen zur sogenannten 'anianischen Reform”, in Mönchtum-Kirche-Herrschaft 750-10oo: Josef Semmler zum 65. Geburtstag, eds. Dieter R. Bauer, Rudolf Hiestand, Brigitte Kasten and Sönke Lorenz (Sigmaringen, 1998), 99-112.

Dieter Geuenich, "Mönche und Konvent von St. Gallen in der Karolingerzeit", Alemannisches Jahrbuch (2003), 39-62.

Hans-Werner Goetz, Strukturen der spätkarolingischen Epoche im Spiegel der Vorstellungen eines zeitgenössischen Mönchs: Eine Interpretation der Gesta Karoli Notkers von St. Gallen (Bonn, 1981).

Eric J. Goldberg, Struggle for Empire: Kingship and Conflict under Louis the German $(817-876)$ (Ithaca NY, 2006).

Martin Gravel, Distances, Rencontres, Communications: Realiser l'Empire sous Charlemagne et Louis le Pieux, (Turnhout 2012).

Olivier Guillot, “Une ordinatio méconnue: le capitulaire de 823-825”, in Charlemagne's Heir: New Perspectives on the Reign of Louis the Pious (814-840), eds. Peter Godman and Roger Collins (Oxford, 1990), 455-86.

Lars Hageneier, Jenseits der Topik: Die karolingische Herrscherbiographie, (Husum 2004). 
Kassius Hallinger, Gorze-Kluny: Studien zu den monastischen Lebensformen und Gegensätzen im Hochmittelalter, Studia Anselmiana 22-25 (Rome, 1950-51).

Jürgen Hannig, Consensus fidelium: Frühfeudale Interpretationen des Verhältnisses von Königtum und Adel am Beispiel des Frankenreiches, Monographien zur Geschichte des Mittelalters 27 (Stuttgart 1982).

Yitzhak Hen, "The Annals of Metz and the Merovingian Past", in The Uses of the Past in the Early Middle Ages, eds. Yitzhak Hen and Matthew Innes (Cambridge, 2000), 175-90.

M.M. Hildebrandt, The External School in Carolingian Society, Education and Society in the Middle Ages and Renaissance 1, (Leiden 1992).

Howe, "The Hagiography of Saint-Wandrille (Fontenelle) (Province of HauteNormandie)", in L'Hagiographie du Haut Moyen Age en Gaule du Nord: Manuscrits, Textes et Centres de Production, ed. Martin Heinzelmann, Beihefte der Francia 52 (Stuttgart, 2001), 127-92.

Walter Kettemann, Subsidia Anianensia: Überlieferungs- und textgeschichtliche Untersuchungen zur Geschichte Witiza-Benedikts, seines Klosters Aniane und zur sogenannten "anianischen Reform", (Duisburg 2000).

Theo Kölzer, Kaiser Ludwig der Fromme (814-840) im Spiegel seiner Urkunden (Paderborn, 2005).

Rutger Kramer, "Justified \& ancient: Bishops and the Bible in the Relatio Compendiensis", in Politische Theologie und Geschichte unter Ludwig dem Frommen/Histoire et Théologie Politiques sous Louis le Pieux, eds. Sören Kaschke and Martin Gravel, Relectio: Karolingische Perspektiven-Perspectives Carolingiennes-Carolingian Perspectives 2 (Ostfildern, forthcoming).

Rutger Kramer, “....ut normam salutiferam cunctis ostenderet': représentations de l'autorité impériale dans la Vita Benedicti Anianensis et la Vita Adalhardi", in Normes et Hagiographie dans l'Occident Chrétien (Ve-XVIe siècles): Actes du Colloque International de Lyon, 4-6 Octobre 2010, eds. Marie-Céline Isaïa and Thomas Granier, Hagiologia 9 (Turnhout, 2014), 101-18.

Anne Latowsky, Emperor of the World: Charlemagne and the Construction of Imperial Authority, 800-1229, (Ithaca, NY 2013).

Christina Lutter, "Affektives Lernen im höfischen und monastischen Gebrauch von exempla", in Funktionsräume, Wahrnehmungsräume, Gefühlsräume: mittelalterliche Lebensformen zwischen Kloster und Hof, ed. Christina Lutter, Veröffentlichungen des Instituts für Österreichische Geschichtsforschung 59 (Vienna, 2011), 121-44.

Simon MacLean, Kingship and Politics in the Late Ninth Century: Charles the Fat and the End of the Carolingian Empire, Cambridge Studies in Medieval Life and Thought, Series 4 vol. 57 (Cambridge, 2003).

Michael Mann, The Sources of Social Power Volume 1: A History of Power from the Beginning to $A D$ 1760, (Cambridge 1986). 
Rosamond McKitterick, The Frankish Church and the Carolingian Reforms 789-895, (London 1977).

Rosamond McKitterick, Charlemagne: The Formation of a European Identity, (Cambridge 2008).

Rosamond McKitterick, "A king on the move: the place of an itinerant court in Charlemagne's government", in Royal Courts in Dynastic States and Empires: A Global Perspective, eds. Jeroen Duindam, Tülay Artan and Metin Kunt, Rulers \& Elites 1 (Leiden, 2011), 145-69.

Anneke B. Mulder-Bakker, "The invention of saintliness: texts and contexts", in The Invention of Saintliness, ed. Anneke B. Mulder-Bakker, Routledge Studies in Medieval Religion and Culture 2 (London, 2002), 3-24.

Janet L. Nelson, "Kingship and Empire", in The Cambridge History of Medieval Political Thought: c. 350-c. 1450, ed. James Henderson Burns (Cambridge, 1988), 211-51.

Janet L. Nelson, "The last years of Louis the Pious", in Charlemagne's Heir: New

Perspectives on the Reign of Louis the Pious (814-840), eds. Peter Godman and Roger Collins (Oxford, 1990), 147-6o.

Janet L. Nelson, "La cour impériale de Charlemagne", in La Royauté et les Élites dans l'Europe Carolingienne, ed. Régine le Jan, (Lille, 1998), 177-91.

Janet L. Nelson, "Aachen as a place of power", in Topographies of Power in the Early Middle Ages, eds. Mayke de Jong, Frans Theuws and Carine van Rhijn, Transformation of the Roman World 6 (Leiden, 2001), 217-41.

Thomas F.X. Noble, “The monastic ideal as a model for empire", Revue Bénédictine 86 (1976), 235-50.

Joaquín Martínez Pizarro, "Images of Church and State: From Sulpicius Severus to Notker Balbulus", The Journal of Medieval Latin (1994), 25-38.

Walter Pohl, "History in fragments: Montecassino's politics of memory", Early Medieval Europe 10 (2001), 343-74.

Janneke Raaijmakers, The Making of the Monastic Community of Fulda, c.744-c.90o (Cambridge, 2012).

Muhammad Mahmoud Rabi', The Political Theory of Ibn Khaldun (Leiden, 1967).

Timothy Reuter, 'Kirchenreform' und 'Kirchenpolitik' im Zeitalter Karl Martells: Begriffe und Wirklichkeit", in Karl Martell in seiner Zeit, ed. Jörg Jarnut, Beihefte der Francia 37 (Sigmaringen, 1994), 34-59.

Anton Scharer, "Charlemagne's Daughters", in Early Medieval Studies in Memory of Patrick Wormald, eds. Stephen Baxter, Catherine Karkov, Janet L. Nelson and David Pelteret, (Farnham, 2009), 269-82.

Percy Ernst Schramm, "Karl der Grosse: Denkart und Grundauffassungen - Die von ihm bewirkte Correctio ("Renaissance"). Historische Zeitschrift 198/2 (1964), 306-345. Josef Semmler, "Studien zum Supplex Libellus und zur anianischen Reform in Fulda", Zeitschrift für Kirchengeschichte 69 (1958), 268-97. 
Josef Semmler, “Pippin III. und die fränkischen Klöster”, Francia 3 (1975), 88-146.

Josef Semmler, "Iussit...princeps renovare...praecepta: zur verfassungsrechtlichen Einordnung der Hochstifte und Abteien in die Karolingische Reichskirche", in Consuetudines monasticae: Festgabe für Kassius Hallinger, eds. Joachim F. Angerer and Josef Lenzenweger, Studia Anselmiana 85 (Rome, 1982), 97-124.

Josef Semmler, "Benedictus II: una regula-una consuetudo", in Benedictine Culture 750-1050, eds. Willem Lourdaux and Daniel Verhelst, Mediaevalia Lovaniensia 1 Studia 11 (Leuven, 1983), 1-49.

Josef Semmler, "Benediktinische Reform und kaiserliches Privileg: Die Klöster im Umkreis Benedikts von Aniane”, in Società, Istituzioni, Spiritualità: Studi in onore di Cinzio Violante, 2 vols., Centro Italiano di Studi sull'Alto Medioevo: Collectanea 1, (Spoleto, 1994), 1:787-832.

Theodor Siegrist, Herrscherbild und Weltsicht bei Notker Balbulus: Untersuchungen zu den Gesta Karoli, (Zürich 1963).

Julia M.H. Smith, "Aedificatio sancti loci: the making of a ninth-century holy place", in Topographies of Power in the Early Middle Ages, eds. Mayke de Jong, Frans Theuws and Carine van Rhijn, Transformation of the Roman World 6 (Leiden, 2001), 361-96.

Julia M.H. Smith, Europe after Rome: A New Cultural History 500-100o, (Oxford 2005).

Michel Sot, Gesta Episcoporum, Gesta Abbatum, Typologie des Sources du Moyen Âge Occidental 37, (Turnhout 1981).

Sita Steckel, Kulturen des Lehrens im Früh- und Hochmittelalter: Autorität, Wissenskonzepte und Netzwerke von Gelehrten, (Cologne 2011).

Edmund E. Stengel, "Die Immunitätsurkunde Ludwigs des Frommen für Kloster Inden (Kornelimünster)”, Neues Archiv der Gesellschaft für ältere deutsche Geschichtskunde 29 (1904), 375-93.

Rachel Stone, Morality and Masculinity in the Carolingian Empire, Cambridge Studies in Medieval Life and Thought, Series 4 vol. 81 (Cambridge, 2012).

Claire Tignolet, "Jeux poétiques à la cour de Charlemagne: compétition et intégration", in Agon: La Competition Ve-XIIe Siècle, eds. François Bougard, Régine Le Jan and Thomas Lienhard, Collection Haut Moyen Âge 17 (Turnhout, 2012), 221-34.

Dorine van Espelo, "A testimony of Carolingian rule? The Codex epistolaris carolinus, its historical context, and the meaning of imperium", Early Medieval Europe 21. 3 (2013), 254-82.

Carine van Rhijn, "Priests and the Carolingian reforms: the bottlenecks of local correctio", in Texts and Identities in the Early Middle Ages, eds. Richard Corradini, Rob Meens, Christina Pössel and Philip Shaw, Forschungen zur Geschichte des Mittelalters 13 (Vienna, 2006), 219-38.

Steven Vanderputten, Monastic Reform as Process: Realities and Representations in Medieval Flanders, 900-110o, (Ithaca NY 2013). 
Jean Verdon, "Recherches sur la chasse en Occident durant le haut moyen âge", Revue Belge de Philologie et d'Histoire $5^{6}$ (1978), 805-29.

Heinrich Wagner, “Zur Notitia de servitio monasteriorum von 819”, Deutsches Archiv für Erforschung des Mittelalters 55 (1999), 417-38.

Ernst Walter, Opus Geminum: Untersuchungen zu einem Formtyp in der mittellateinischen Literatur, (Erlangen 1973).

Karl-Ferdinand Werner, "Hludovicus Augustus: Gouverner l'empire chrétien-Idées et réalités", in Charlemagne's Heir: New Perspectives on the Reign of Louis the Pious (814-84o), eds. Peter Godman and Roger Collins (Oxford, 1990), 3-123.

Chris Wickham, The Inheritance of Rome: A History of Europe from 400 to 10oo, (London 2009).

Bernhard Zeller, "Karolingisches Imperium und regionales Urkundenwesen am Beispiel Sankt Gallens", in Von Stadtstaaten und Imperien: Kleinterritorien und Großreiche im historischen Vergleich-Berichtdes 24. Österreichischen Historikertages, Innsbruck, 20-23. September 2005, eds. Christoph Haidacher and Richard Schober (Innsbruck, 2006), 65-72.

Alfons Zettler, "St. Gallen als Bischofs- und Königskloster", Alemanisches Jahrbuch (2003), 23-28. 